\title{
Postawy i reakcje polskiego społeczeństwa wobec zanieczyszczenia środowiska naturalnego w kraju (1971-1989)
}

Zarys treści: $\mathrm{W}$ artykule na wybranych przykładach przedstawiono postawy polskiego społeczeństwa względem degradacji ekosystemu w dwóch ostatnich dekadach PRL. W latach siedemdziesiątych i osiemdziesiątych XX w., w sytuacji wyraźnie zarysowującego się kryzysu ekologicznego, wśród polskiego społeczeństwa zaczęły ujawniać się postawy i działania zmierzające do zahamowania tego negatywnego procesu. Inicjatywy podejmowane na rzecz ochrony środowiska naturalnego były m.in. konsekwencją kształtowania świadomości ekologicznej Polaków.

Słowa kluczowe: zanieczyszczenie środowiska, katastrofa ekologiczna, świadomość ekologiczna, postawy społeczne

Keywords: environment pollution, ecological disaster, environmental awareness, social attitudes

Zainteresowanie problematyką „postaw” znajduje swój wyraz zarówno w rozważaniach teoretycznych, jak i w licznych badaniach empirycznych. Początek tych analiz w naukach społecznych zawdzięczamy Williamowi I. Thomasowi i Florianowi Znanieckiemu. We wstępie do Polish Peasant in Europe and America (Boston 1918-1920) wspomniani badacze wprowadzili pojęcie „postawy” dla oznaczenia procesów indywidualnej świadomości, determinujących zarówno aktualne, jak i potencjalne reakcje każdej osoby wobec społecznego świata. W ich ujęciu, „postawa” jest zawsze postawą wobec jakiejś wartości, przy czym za wartość uznają „jakikolwiek fakt mający empiryczną treść, dostępną dla członków określonej grupy społecznej i znaczenie, zgodnie z którym jest lub może być obiektem działania"1.

W kolejnych latach problematyką „postaw” zainteresowali się przedstawiciele wielu nauk: psychologii, socjologii, pedagogiki, filozofii i innych. Warto podkreślić, że w toku prowadzonych badań w obrębie każdej z nich były tworzone

\footnotetext{
${ }^{1}$ Cytat za M. Marody, Sens teoretyczny a sens empiryczny pojęcia postawy. Analiza metodologiczna zasad doboru wskaźników w badaniach nad postawami, Warszawa 1976, s. 12.
} 
odrębne definicje, dlatego trudno jednoznacznie wyjaśnić termin „postawy”. Był (i jest) on pojęciem wieloznacznym i nie ma jednego sposobu jego rozumienia i definiowania.

Dla celów poniższego artykułu najwłaściwsza wydaje się jednak definicja sformułowana na gruncie badań socjologicznych przez Stefana Nowaka. Dla autora „postawą pewnego człowieka wobec pewnego przedmiotu jest ogół względnie trwałych dyspozycji do oceniania tego przedmiotu i emocjonalnego nań reagowania oraz ewentualnie towarzyszących emocjonalno-oceniającym dyspozycjom względnie trwałych przekonań o naturze i własnościach tego przedmiotu i względnie trwałych dyspozycjach do zachowanie się wobec tego przedmiotu"2. Warto również podkreślić, że definicja ta obejmuje wszystkie najważniejsze elementy w badaniach postaw. Odwołuje się do doświadczeń behawioryzmu oraz badań nad motywacjami postaw, określa elementy związane z przekonaniami podmiotu i dokonywaną przez niego oceną, wreszcie odwołuje się do emocji jako ważnej części składowej postaw.

Analiza postaw społecznych może przynieść również wartościowe rezultaty w badaniach nad środowiskową historią powojennej Polski. Uchwycenie postaw, emocji oraz reakcji polskiego społeczeństwa wobec postępującego procesu zanieczyszczenia środowiska naturalnego (oraz wszelkich zmian w tym zakresie) będzie z całą pewnością cenne z poznawczego punktu widzenia. Najwłaściwszą cezurą dla tych badań wydają się być lata 1971-1989. W ostatnich dwóch dekadach PRL nastąpiła istotna zmiana podejścia do problemów ochrony środowiska naturalnego w kraju. Działania (przynajmniej pozorne $e^{3}$ ) w tym obszarze zaczęły podejmować władze partyjno-państwowe. W głównej mierze skupiały się one na próbach sformalizowania i zinstytucjonalizowania polityki zmierzającej do zahamowania degradacji ekosystemu oraz zachowania jego naturalnych walorów. W 1972 r. powołano Ministerstwo Gospodarki Terenowej i Ochrony Środowiska ${ }^{4}$.

\footnotetext{
2 Zob.: S. Nowak, Pojęcie postawy w teoriach i stosowanych badaniach społecznych, w: Teorie postaw, red. idem, Warszawa 1973, s. 18.

${ }^{3}$ Pozorność działań podejmowanych przez władze partyjno-państwowe dobrze obrazuje sprawa budowy elektrociepłowni w Kielcach, która został przedstawiona w dalszej części artykułu. Problem fasadowości ustawodawstwa na rzecz ochrony środowiska w PRL porusza również w wywiadzie dla „Natura, Człowiek. Dodatek Specjalny Tygodnika Powszechnego” Ryszard Gawlik (polski ekolog, opozycjonista, członek ruchu „Wolność i Pokój”). Zauważa on, że w Polsce Ludowej „istniało nawet szczegółowe prawodawstwo ochrony środowiska, które rzekomo miało chronić przyrodę i wymierzać kary trucicielom. Były to jednak gesty pozorowane, bo priorytety władza określiła jasno: gospodarka miała produkować coraz więcej, za wszelką cenę. Kary można było przecież umorzyć za względu na "potrzeby socjalistycznej ojczyzny i mieszkańców miast i wsi»". Zob.: Bunt. Ekologia w komunizmie, „Natura, Człowiek. Dodatek Specjalny Tygodnika Powszechnego" 17 IV 2011, nr 16, s. 1.

${ }^{4}$ Zob.: Dz.U. 1972, nr 11, poz. 77, Ustawa z dnia 29 III 1972 r. o utworzeniu urzędu Ministra Gospodarki Terenowej i Ochrony Środowiska.
} 
W kolejnych latach było ono kilkukrotnie przekształcane, by w 1985 r. ukonstytuować się w postaci Ministerstwa Ochrony Środowiska i Zasobów Naturalnych ${ }^{5}$ W omawianym okresie podjęto również prace nad licznymi regulacjami prawnymi, których głównym celem była ochrona środowiska. W tym miejscu można wymienić chociażby prawo wodne, uchwalone w 1974 r. ${ }^{6}$, czy też ustawę o ochronie i kształtowaniu środowiska z $1980 \mathrm{r}{ }^{7}$ W pierwszej połowie dekady gierkowskiej funkcjonować zaczęly także wojewódzkie ośrodki badań i kontroli środowiska, które przejęły zadania wcześniej realizowane przez laboratoria badań wód i ścieków ${ }^{8}$. Nie były to oczywiście jedyne instytucje odpowiedzialne za kontrolę stanu środowiska naturalnego w kraju?

Dodatkowo w latach 1971-1989 można zaobserwować proces kształtowania świadomości ekologicznej polskiego społeczeństwa ${ }^{10}$. Zaangażowanie w inicjatywy oddolne na rzecz ochrony środowiska naturalnego może świadczyć o głębokich przemianach w postawach Polaków wobec degradacji ekosystemu w kraju. Kształtowanie wrażliwości ekologicznej widoczne jest również w działalności organizacji przyrodniczych, które w omawianym okresie coraz liczniej zaczęły powstawać w tzw. Polsce Ludowej.

W latach osiemdziesiątych XX w. szacowano, że w PRL ruch proekologiczny obejmował ok. 40 organizacji formalnych i ok. 20 grup nieformalnych, które bezpośrednio zajmowały się ochroną środowiska naturalnego. Wśród najważniejszych i najbardziej aktywnych można wymienić: Ligę Ochrony Przyrody, Polski Klub Ekologiczny, Ekologiczny Ruch Społeczny, ruch „Wolność i Pokój” oraz „Wolę być". Ponadto funkcjonowało także ok. 60 instytucji politycznych, społecznych, zawodowych, młodzieżowych, które uwzględniały w swych programach problematykę ekologiczną. Warto również wspomnieć, że 14 września 1988 r. w Krakowie

${ }^{5}$ Zob.: Dz.U. 1975, nr 16, poz. 90, Ustawa z dnia 28 V 1975 r. o utworzeniu urzędu Ministra Administracji, Gospodarki Terenowej i Ochrony Środowiska; Dz.U. 1983, nr 44, poz. 201, Ustawa z dnia 28 VII 1983 r. o utworzeniu Urzędu Ochrony Środowiska i Gospodarki Wodnej; Dz.U. 1985 , nr 50, poz. 262, Ustawa z dnia 12 XI 1985 r. o zmianach w organizacji oraz zakresie działania niektórych naczelnych i centralnych organów administracji państwowej.

${ }^{6}$ Zob.: Dz.U. 1974, nr 38, poz. 230, Ustawa z dnia 24 X 1974 r. Prawo wodne.

7 Zob.: Dz.U. 1980, nr 3, poz. 6, Ustawa z dnia 31 I 1980 r. o ochronie i kształtowaniu środowiska.

${ }^{8}$ APK, WOBiKŚ w Kielcach, sygn. 46, Informacja o działalności własnej Wojewódzkiego Ośrodka Badań i Kontroli Środowiska w Kielcach, Kielce, kwiecień 1976 r., k. 10-11.

${ }^{9}$ Wśród innych instytucji odpowiedzialnych za stan środowiska naturalnego w Polsce można wymienić: Państwową Inspekcję Ochrony Środowiska, na czele której stał główny inspektor ochrony środowiska, Instytut Kształtowania Środowiska czy też stacje sanitarno-epidemiologiczne w poszczególnych województwach.

${ }^{10}$ Jak zauważają Jacek i Kazimiera Wodzowie termin „świadomość ekologiczna” jest „wyrazem zainteresowania, jakie grupy społeczne szczególnie wyczulone na stan naszego środowiska naturalnego wyrażały w sposób publiczny, począwszy od lat sześćdziesiątych". Zob.: J. Wódz, K. Wódz, Świadomość ekologiczna, w: Zarządzanie środowiskiem, cz. 1, red. Z. Nowak, Gliwice 2001, s. 171-181. 
zebrała się grupa inicjatywna Polskiej Partii Ekologicznej. Następnie w grudniu 1988 r., ponownie w Krakowie, miał miejsce Kongres Założycielski partii. W tym czasie wszystkie koła okręgowe miały obejmować ok. 2000 członków ${ }^{11}$.

W tym miejscu warto zastanowić się, czym była (i jest w dalszym ciągu) wspomniana „świadomość ekologiczna” polskiego społeczeństwa, a także jak przebiegał proces jej kształtowania w omawianym okresie.

Socjolodzy przyznają otwarcie, że dotychczas nie udało się w pełni i ostatecznie zdefiniować kategorii socjologicznej zwanej „świadomością ekologiczną”. Dodatkowo są oni przekonani, że, biorąc pod uwagę wielość paradygmatów tej dyscypliny, taki stan rzeczy będzie się utrzymywał ${ }^{12}$. Szukając jednak najbardziej ogólnej definicji analizowanego zagadnienia, można uznać, że świadomość ekologiczna „oznacza całokształt uznawanych idei, wartości, opinii o środowisku jako miejscu życia i rozwoju człowieka (społeczeństwa), wspólnym dla określonych grup społecznych w danym okresie historycznym". Natomiast w znaczeniu węższym, będzie to „stan wiedzy, poglądów, wyobrażeń ludzi o roli środowiska w życiu człowieka, jego antropogennym obciążeniu, stopniu wyeksploatowania, zagrożenia i ochrony, w tym także stan wiedzy o sposobach i narzędziach zarządzania użytkowaniem, ochroną i kształtowaniem środowiska"13.

Świadomość ekologiczna człowieka kształtowała się w trakcie złożonego procesu pod wpływem ogólnie przyjętych (zmieniających się) norm społecznych, informacji w środkach masowego przekazu, formalnej i nieformalnej edukacji ekologicznej, a także działań państwa. Na proces kształtowania świadomości ekologicznej wpływało również miejsce zamieszkania ${ }^{14}$. Można przypuszczać, że w tzw. Polsce Ludowej powstawała ona najszybciej na obszarach zdegradowanych, pod wpływem obserwacji skutków niekorzystnego oddziaływania przemysłu na środowisko naturalne. Potwierdzeniem tej tezy mogą być słowa Tadeusza Burgera, który w jednym z artykułów pisał, że w Polsce „wobec braków edukacyjnych i informacyjnych zagrożenia ekologiczne ludzie poznawali «na własnej skórze». Stąd też robotnik z Tarnobrzega wiedział więcej o ekologii niż lekarz z Poznania"15.

11 Zob.: AIPN, BU, MSW, sygn. 1585/3698, Tendencje rozwoju ruchów proekologicznych w Polsce z uwzględnieniem problemów społecznych budowy elektrowni atomowych, Warszawa, grudzień 1988 r., k. 5 i 16.

12 A. Papuziński, Świadomość ekologiczna w świetle teorii i praktyki, „Problemy Ekorozwoju” 2006, nr 1, s. 35 .

${ }^{13}$ Zarządzanie środowiskiem, red. B. Poskrobko, Warszawa 2007, s. 61.

${ }^{14} \mathrm{~J}$. Nycz-Wróbel, Świadomość ekologiczna społeczeństwa i wynikające z niej zagrożenia środowiska naturalnego (na przykładzie opinii mieszkańców województwa podkarpackiego), „Zeszyty Naukowe Politechniki Rzeszowskiej. Ekonomia i Nauki Humanistyczne” 2012, z. 19, nr 3, s. 64.

${ }^{15}$ T. Burger, Konflikty i współdziałanie. Świadomość ekologiczna i postawy społeczeństwa, w: Świadomość ekologiczna i społeczne ruchy „Zielonych” w Polsce, red. W. Mirowski, Warszawa 1999, s. 37. 
Jak zmieniała się świadomość ekologiczna społeczeństwa w ostatnim dwudziestoleciu istnienia PRL? Przy próbie odpowiedzi na to pytanie pomocne mogą okazać się wyniki badań ankietowych przeprowadzonych przez Ośrodek Badania Opinii Publicznej i Studiów Programowych w lipcu 1975 r. oraz w październiku $1992 \mathrm{r}$.

Wyniki ankiety przeprowadzonej w 1975 r. mogą świadczyć o słabym zorientowaniu społeczeństwa $\mathrm{w}$ sprawach związanych $\mathrm{z}$ zanieczyszczeniem środowiska w Polsce. Około 75\% badanych było zadowolonych z podstawowych elementów środowiska w miejscu zamieszkania (negatywne opinie wyrażali głównie mieszkańcy dużych miast). Ponadto $47 \%$ rozmówców wyrażało przekonanie, że w Polsce działalność na rzecz ochrony środowiska jest wystarczająca, a 57\% respondentów stwierdziło, iż przemysł i nowe technologie „poradzą sobie z zanieczyszczeniem przyrody, które spowodowały"16.

W kolejnych latach zaszły znaczne zmiany pod tym względem. W $1992 \mathrm{r}$. wśród respondentów dominowało przekonanie, że region kraju, który zamieszkują, jest zanieczyszczony (w znacznym stopniu - 48\% badanych, średnim - 47\%). Ankietowani stwierdzili również, że w Polsce nie robi się zbyt wiele (bądź nie robi się nic) w zakresie ochrony środowiska, a zanieczyszczenie przyrody będzie postępowało (łącznie 79\% badanych wyrażało taką opinię). Jednocześnie można dostrzec pewne objawy bierności społeczeństwa wobec degradacji przyrody - 22\% respondentów stwierdziło, że zwykły obywatel nic nie może zrobić w zakresie ochrony środowiska, a 57\% uważało, iż może zrobić niewiele ${ }^{17}$.

Można założyć, że wszelkie różnice w odpowiedziach na pytania zadane w obu badaniach były właśnie wynikiem procesu kształtowania świadomości ekologicznej, a także efektem zmieniających się postaw społecznych względem zanieczyszczenia środowiska naturalnego w kraju. Opierając się na wynikach badań przeprowadzonych przez OBOPiSP, można stwierdzić, że w ciągu siedemnastu lat znacznie wzrosła wrażliwość ekologiczna Polaków, a także troska o stan ekosystemu w ich najbliższym otoczeniu.

W latach osiemdziesiątych i dziewięćdziesiątych XX w. kontynuowano badania w celu poznania świadomości ekologicznej społeczeństwa polskiego. W okresie tym przeprowadzono kilkanaście różnego rodzaju analiz, jednak żadna z nich nie miała charakteru ani całkowicie reprezentatywnego, ani w pełni dokumentującego problem. Wyniki badań pozwalają jednak postawić tezę, że społeczeństwo w Polsce w połowie lat dziewięćdziesiątych XX w. było w końcowej fazie kształtowania świadomości ekologicznej. Jaskrawym dowodem na to są wyniki badań przeprowadzonych w przedsiębiorstwach przemysłowych szczególnie uciążliwych

${ }^{16}$ OBOPiSP, Problemy zagrożenia i ochrony środowiska naturalnego w opinii publicznej, sygn. 22/63, lipiec 1975 r., s. 1-3, obop-arch.tnsglobal.pl/archive (dostęp: 7 XII 2015).

${ }^{17}$ OBOPiSP, Sprawy środowiska naturalnego, sygn. 1015a, październik 1992 r., s. 3-5, obop-arch. tnsglobal.pl/archive (dostęp: 7 XII 2015). 
dla środowiska naturalnego. W 1985 r. co drugi respondent uważał, że zanieczyszczenie środowiska nie ma nic wspólnego $\mathrm{z}$ funkcjonowaniem jego zakładu, w 1993 r. takich odpowiedzi było już tylko 7\%. Większość ankietowanych w tych przedsiębiorstwach w ciągu ośmiu lat wyszła więc ze stadium fałszywej świadomości ekologicznej ${ }^{18}$.

Jednocześnie jednak w dalszym ciągu można było dostrzec bierność znacznej części polskiego społeczeństwa w podejmowaniu inicjatyw na rzecz ochrony środowiska. W głównej mierze było to spowodowane faktem, iż świadomości Polaków o postępującej degradacji ekosystemu w kraju towarzyszyło przekonanie o indywidualnej bezradności wobec tego zjawiska.

$\mathrm{W}$ jednej z ankiet zorganizowanej przez OBOPiSP respondentom postawiono pytanie: czy zwykły człowiek może ochronić siebie/swoją rodzinę przed zanieczyszczeniami środowiska przyrodniczego? Zdecydowana większość pytanych (67\%) przyznała się do całkowitej bezradności w tym zakresie. Co więcej, duża część ankietowanych stwierdziła, że sposoby ochrony jednostkowej po prostu „nie istnieją". Warto również podkreślić, że większość badanych $(62,4 \%)$ nie słyszała o jakichkolwiek działaniach na rzecz ochrony środowiska przyrodniczego podejmowanych przez zwykłych obywateli. Oznaczało to, że zdecydowana większość społeczeństwa nie miała żadnej wiedzy o ruchu ekologicznym w Polsce i możliwościach samoorganizowania się. Na potwierdzenie powyższej tezy można również przytoczyć wyniki badań nad źródłami zagrożeń ekologicznych wśród określonych grup pracowniczych przedsiębiorstw przemysłowych uciążliwych dla środowiska naturalnego, przeprowadzonych w 1987 r. przez Bazylego Poskrobko. Autor wskazał na występowanie w polskim społeczeństwie specyficznej kategorii tzw. pozornej świadomości ekologicznej, przejawiającej się tym, że każdy chciałby, aby otaczające go środowisko przyrodnicze było czyste. Jednak niewiele osób (w tym przypadku robotnicy wielkoprzemysłowi) zdawało sobie sprawę, że uczestnicząc w procesach produkcyjnych, sami przyczyniają się do jego zanieczyszczenia ${ }^{19}$.

Można również zaryzykować stwierdzenie, że aktywność Polaków na polu ochrony środowiska wzrastała w sytuacjach bezpośredniego zagrożenia skutkami zanieczyszczenia ekosystemu. Stąd, jak się wydaje, najwięcej przykładów inicjatyw podejmowanych na rzecz środowiska naturalnego można odnaleźć wśród działalności społeczności lokalnych (m.in. wiejskich czy osiedlowych). Kwestia ta zostanie jeszcze wspomniana w dalszej części artykułu.

Mimo tej specyficznej dwubiegunowości zachowań (przeświadczenie o pogarszającym się stanie ekosystemu w kraju przy jednoczesnym braku wiedzy

${ }_{18}$ Zob.: K. Górka, B. Poskrobko, W. Radecki, Ochrona środowiska. Problemy społeczne, ekonomiczne i prawne, Warszawa 1998, s. 35-37.

${ }^{19}$ Zob.: OBOPiSP, Świadomość ekologiczna społeczeństwa polskiego, sygn. 1015b, październik 1992 r., s. 6 i 9, obop-arch.tnsglobal.pl/archive (dostęp: 7 XII 2015). Zob. też: B. Poskrobko, Jak postrzegamy ochronę środowiska, „Aura” 1987, nr 8 i 10, s. 12-13 i 3-4. 
o formach zapobiegania temu procesowi) w omawianym okresie można wskazać wiele postaw polskiego społeczeństwa wynikających z kształtowania się świadomość ekologicznej. W moim przekonaniu postawy te można podzielić na trzy kategorie, z których każda zachodziła na innej płaszczyźnie. Najogólniej rzecz ujmując, podział ten można przedstawić w następujący sposób:

1. Płaszczyzna ponadregionalna (międzyregionalna).

2. Płaszczyzna regionalna.

3. Płaszczyzna lokalna.

\section{Płaszczyzna ponadregionalna}

Odnosi się ona do zjawisk zachodzących w skali makro. Do tej kategorii można zaliczyć wszelkie zachowania i postawy polskiego społeczeństwa odnośnie do zanieczyszczenia środowiska w całym kraju, a nawet szerzej - problemów globalnych związanych z ekologią.

Wśród najbardziej reprezentatywnych przykładów zachowań wpisujących się $\mathrm{w}$ ramy płaszczyzny ponadregionalnej można z pewnością wymienić rekcję polskiego społeczeństwa na katastrofę w elektrowni jądrowej w Czarnobylu, a także - wynikające pośrednio z tego wydarzenia - protesty wobec budowy elektrowni atomowej „Żarnowiec”.

Katastrofa w Czarnobylu, do której doszło w nocy z 25 na 26 kwietnia 1986 r., znalazła już swoje miejsce w literaturze przedmiotu ${ }^{20}$, dlatego w tym miejscu zrezygnowałem $z$ dokładnego przedstawienia jej bezpośrednich konsekwencji w Polsce ${ }^{21}$. Warto jednak podkreślić, że wydarzenie to było momentem przełomowym w procesie kształtowania się świadomości ekologicznej. Sama katastrofa w czarnobylskim reaktorze wyjątkowo mocno odcisnęła się także w pamięci Polaków, czego ślad można odnaleźć w badaniach na temat społecznego stosunku do energii jądrowej22.

${ }^{20}$ Szerzej o przyczynach i przebiegu samej awarii: W. Siwiński, Czarnobyl. Od katastrofy do procesu, Warszawa 1989, s. 14-29. Katastrofa w Czarnobylu została opisana w wielu publikacjach, np.: G. Miedwiediew, Raport z Czarnobyla, tłum. A. Tyszkowska-Gosk, T. Gosk, Warszawa 1991; P.P. Read, Czarnobyl. Zapis faktów, tłum. J. Kubowski, Warszawa 1996; S. Aleksijewicz, Krzyk Czarnobyla, tłum. L. Wołosiuk, Warszawa 2000; I. Kostin, Czarnobyl. Spowiedź reportera, tłum. W. Melech, Warszawa 2006; M. Mycio, Piołunowy las. Historia Czarnobyla, Poznań 2006.

${ }^{21}$ Zob. np.: Nazajutrz. Reakcje społeczeństwa polskiego na katastrofę w Czarnobylu, red. A. Siciński, Warszawa 1989; J. Sadowska, Czarnobyl - oblicza pamięci o wielkim strachu, „Biuletyn Historii Pogranicza” 2011, nr 11, s. 95-106; J. Dulewicz, M. Zawisza, Społeczeństwo polskie wobec katastrofy w elektrowni w Czarnobylu, w: Od powietrza, głodu i wojny... Klęski elementarne na przestrzeni wieków, red. T. Głowiński, E. Kościk, Wrocław 2013, s. 317-330; J. Dulewicz, Katastrofa w Czarnobylu i jej wpływ na sytuacje w Polsce, w: Zimowa Szkoła Historii Najnowszej 2014, red. M. Hańderek, Ł. Kamiński, Warszawa 2015, s. 87-94.

${ }_{22}$ M. Szostek, Świadomość ekologiczna polskiego społeczeństwa, w: Wartości i zmiany. Przemiany postaw Polaków w jednoczącej się Europie, red. A. Jasińska-Kania, Warszawa 2012, s. 243. 
Za największy sukces (oczywiście z perspektywy lokalnej społeczności) oddolnej inicjatywy społecznej związanej z energią atomową należy z całą pewnością uznać doprowadzenie do wstrzymania budowy Elektrowni Jądrowej „Żarnowiec" (EJŻ). Inwestycja już z chwilą jej rozpoczęcia budziła wiele kontrowersji. Pierwsze protesty przeciw budowie EJŻ miały miejsce pod koniec $1984 \mathrm{r}$., a ich organizatorem był Polski Klub Ekologiczny. Słabe nagłośnienie i trzymanie się legalnych form protestu sprawiło, że nie przyniosły one jednak żadnych skutków. Sytuacja zmieniła się radykalnie dopiero po awarii w Czarnobylu i włączeniu się do działań przeciw budowie elektrowni grup nieformalnych, które nie dbały o przestrzeganie legalności protestu. Przyjęcie nowych form działania widać chociażby w pierwszych akcjach zorganizowanych przez Ruch „Wolność i Pokój”. W tym miejscu można wymienić demonstrację w Krakowie, która miała miejsce 1 maja 1986 r., protest sitingowy na ulicy Świdnickiej (2 maja) i marsz kobiet z dziećmi w wózkach (9 maja) we Wrocławiu oraz wielotysięczny pochód w Krakowie ( 1 czerwca). Oryginalny charakter przybrała pikieta w Gdańsku 16 października 1987 r. Czterech członków WiP przebranych za zwierzęta weszło na dach apteki we Wrzeszczu, rozwieszając tam transparent i rozrzucając ulotki wśród zbierających się wokół budynku ludzi. Akcje protestacyjne zaczęły przybierać na sile pod koniec lat osiemdziesiątych. W lutym 1989 r. obyła się demonstracja na Długim Targu w Gdańsku. Zdaniem SB w manifestacji wzięło udział ok. 70 działaczy i ok. 200, a w kulminacyjnym momencie ok. 1000 osób. Dodatkowo organizatorzy protestu zdecydowali się na jego cotygodniową kontynuację (akcja trwała do wakacji). W marcu 1989 r. analogiczne demonstracje rozpoczęły się w Poznaniu, gdzie protestowano przeciw planowanej budowie drugiej elektrowni jądrowej w Klempiczu ${ }^{23}$.

W rezultacie intensywnej akcji protestacyjnej władze zostały zmuszone do zorganizowania lokalnego referendum w sprawie kontynuacji budowy elektrowni w Żarnowcu. Pierwotna decyzja o głosowaniu zapadła już w 1987 r., ale była pod rozmaitymi pretekstami odkładana aż do wyborów samorządowych w $1990 \mathrm{r}$. Referendum poprzedziły szeroko zakrojone akcje ulotkowe i plakatowe gdańskich organizacji ekologicznych. Ostatecznie w badaniu opinii publicznej wzięło udział $44,3 \%$ uprawnionych do głosowania, z których $86,1 \%$ odpowiedziało się przeciw budowie, a $13,9 \%-\mathrm{za}^{24}$.

\section{Płaszczyzna regionalna}

W jej ramy można wpisać inicjatywy podejmowane przez mieszkańców dużych rejonów (np. okręgów przemysłowych), województw, a także pojedynczych miast. Głównym czynnikiem, który decyduje o zakwalifikowaniu poszczególnych spraw

\footnotetext{
${ }^{23}$ J. Waluszko, Protesty przeciwko budowie elektrowni jądrowej Żarnowiec w latach 1985-1990, Gdańsk 2013, s. 36-57.

${ }^{24}$ J. Dulewicz, M. Zawisza, op. cit., s. 329.
} 
do tej konkretnej płaszczyzny, jest fakt zaangażowania większej społeczności w problematykę ochrony środowiska naturalnego w bliskim sąsiedztwie.

W zaproponowane założenia dobrze wpisuje się pożar, który miał miejsce 21 maja 1986 r. w Zakładach Chemicznych „Organika-Benzyl” w Skarżysku-Kamiennej, a także wszystkie konsekwencje związane $\mathrm{z}$ tym wydarzeniem. Początki tego przedsiębiorstwa sięgają lat pięćdziesiątych XX w., kiedy w mieście zaczęła funkcjonować Spółdzielnia Pracy Laboratorium Chemiczne. Fabryka została zlokalizowana $\mathrm{w}$ dziewiętnastowiecznych obiektach hutniczych w południowo-wschodniej części Skarżyska. W 1976 r. przedsiębiorstwo zostało podporządkowane bezpośrednio Ministerstwu Przemysłu Chemicznego i Lekkiego, przyjmując jednocześnie nazwę Zakłady Chemiczne „Organika-Benzyl”25. Głównymi odbiorcami półfabrykatów oraz substancji chemicznych tam produkowanych był przemysł: farmaceutyczny, kosmetyczny i tworzyw sztucznych ${ }^{26}$.

W pobliżu „Benzylu” w kolejnych latach wybudowano lub rozbudowano liczne zakłady przemysłowe różnych specjalizacji. W latach osiemdziesiątych XX w. na terenie dzielnicy Dolna Kamienna znajdowało się 17 przedsiębiorstw, a wśród nich do najważniejszych można zaliczyć: Zakład Części Hamulcowych FSC, Zakład Produkcji Rynkowej Z-7 „Mesko”, Zakład Metalowy Spółdzielni „Brzask” i wydział Odlewni Żeliwa i Emalierni „Kamienna”27. Panująca na terenach przemysłowych ciasnota właściwie uniemożliwiała podjęcie jakichkolwiek prac modernizacyjnych czy budowlanych. Doskonałym przykładem tych problemów był m.in. Zakład Chemiczny „Organika-Benzyl”, gdzie praca w starych halach wpływała niekorzystnie na zdrowie robotników, a także była obarczona dużym zagrożeniem wypadkowym. Ponadto niewłaściwe składowanie materiałów i odpadów poprodukcyjnych, które przechowywane były na placu przyzakładowym, stwarzało niebezpieczeństwo wystąpienia pożarów (wyjątkowo groźnych w branży chemicznej). Z kolei dla mieszkańców dzielnicy Dolna Kamienna szczególnie uciążliwe były efekty uboczne produkcji przedsiębiorstwa. Badania przeprowadzone przez Wojewódzki Ośrodek Badań i Kontroli Środowiska na obszarze w pobliżu „Benzylu” w okresie od sierpnia 1983 do listopada 1985 r. wykazały wielokrotne przekroczenie dopuszczalnych norm stężeń zawiązków chemicznych. Przykładowo poza ogrodzeniem zakładu stężenie chlorowodoru sięgało od 654 do 1761\% NDS (najwyższe dopuszczalne stężenie), a toluenu od

${ }^{25}$ APK, MRN w Skarżysku-Kamiennej, sygn. 176, Odpowiedź na interpelację posła Zbigniewa Sowy z dnia 1986-06-17 w sprawie ochrony środowiska w związku z działalnością Zakładów Chemicznych „Organika-Benzyl” w Skarżysku-Kamiennej, Warszawa, lipiec 1986 r., k. 55; APK, MRN w Skarżysku-Kamiennej, sygn. 27, Opinia Wydziału Ochrony Środowiska, Gospodarki Wodnej i Geologii Urzędu Wojewódzkiego w sprawie ochrony środowiska w Zakładach Chemicznych „Organika-Benzyl” w Skarżysku-Kam., 1986 r., k. 59.

${ }^{26}$ W. Kasiński, Wygrali z ogniem w piekle, „Przegląd Pożarniczy” 1986, nr 10, s. 8.

${ }^{27}$ APK, MRN w Skarżysku-Kamiennej, sygn. 17, Protokół nr XV/86 nadzwyczajnej sesji Miejskiej Rady Narodowej w Skarżysku-Kamiennej odbytej w dniu 9 VI 1986 r., k. 408. 
882 do 6138\% NDS. Stężenia związków chemicznych w dzielnicy Dolna Kamienna były również wyczuwalne zmysłami wzroku i powonienia ${ }^{28}$.

Znaczne przekroczenie norm stężeń związków chemicznych wykazała już wizytacja przeprowadzona przez Państwową Inspekcję Pracy w 1980 r. Doprowadziło to do wydania decyzji o wstrzymaniu z dniem 30 czerwca 1980 r. pracy w zakładzie i zmiany produkcji na mniej uciążliwą. W tym samym roku z niezrozumiałych względów Zarząd Główny Związku Zawodowego Chemików przesunął termin realizacji wspomnianej decyzji o pięć lat, tj. do 31 grudnia 1985 r. ${ }^{29}$ Prawdopodobnie zmiana daty była podyktowana potrzebami gospodarki państwowej. Okres ten miał zapewne umożliwić przejęcie produkcji przez inne zakłady chemiczne w kraju.

Mimo późniejszych wniosków kierownictwa zakładu decyzja o wstrzymaniu produkcji w „Benzylu” została utrzymana. Oznacza to, że od 1 stycznia 1986 r. przedsiębiorstwo faktycznie działało wbrew nakazowi Inspekcji Pracy. „Benzyl” nie posiadał $\mathrm{w}$ tym czasie ważnego pozwolenia wodno-prawnego, oczyszczalni ścieków, uporządkowanej gospodarki odpadami i strefy ochronnej.W takiej sytuacji doszło do pożaru, który wybuchł w zakładzie 21 maja 1986 r. o godzinie 16.15. Warto również nadmienić, że nie było to pierwsze tego typu zdarzenie w fabryce. Mniejsze pożary miały miejsce w 1979 i w 1980 r. $^{30}$

Do zaprószenia ognia doszło prawdopodobnie na prowizorycznym składowisku, gdzie w wyniku nagrzania szklanych pojemników zapaliły się chemiczne półfabrykaty. Część załogi przystąpiła do gaszenia pożaru dostępnym sprzętem (gaśnice pianowe oraz woda $\mathrm{z}$ hydrantu), inni natomiast, w obawie przed narażeniem zdrowia w wyniku grożącego oddziaływania toksycznego, opuścili teren przedsiębiorstwa. W tym samym czasie została poinformowana straż pożarna, która szybko pojawiła się na miejscu wypadku. Akcja gaśnicza, w której wzięło udział 25 sekcji strażackich, zakończyła się o godzinie $18.30^{31}$.

Konsekwencje pożaru w „Benzylu” były poważne. W związku z zatruciem toksynami do szpitala trafiło 150 osób (głownie biorących udział w akcji gaśniczej).

${ }^{28}$ APK, MRN w Skarżysku-Kamiennej, sygn. 17, Wystąpienie Komisji Gospodarki Komunalnej, Mieszkaniowej i Ochrony Środowiska MRN Skarżysko na nadzwyczajnej sesji MRN w dniu 9 VI 1986 r., k. 444.

${ }^{29}$ APK, MRN w Skarżysku-Kamiennej, sygn. 27, [Pismo Państwowej Inspekcji Pracy do I Sekretarza Komitetu Wojewódzkiego PZPR w Kielcach], Kielce, 27 V 1986 r., k. 65-66.

${ }^{30}$ W. Kasiński, op. cit., s. 8-9. Zob. też: AIPN Kielce, WUSW w Kielcach, sygn. 014/670, Sprawa operacyjnego sprawdzenia dot. możliwości zatrucia wód rzeki Kamienna przez odpady produkcyjne gromadzone bez właściwego zabezpieczenia na składowisku Zakładów Chemicznych „Organika-Benzyl” w Skarżysku-Kamiennej. Informacja o pożarze, Skarżysko-Kamienna, $25 \mathrm{~V}$ 1979 r., k. 24-26.

${ }^{31}$ APK, MRN w Skarżysku-Kamiennej, sygn. 176, Protokół nr 1 narady, która odbyła się w dniu 1986.07.15 w Ministerstwie Przemysłu Chemicznego i Lekkiego w sprawie Zakładów Chemicznych „Organika-Benzyl” w Skarżysku-Kamiennej, Warszawa, 31 VII 1986 r., k. 35-35v; W. Kasiński, op. cit., s. 9-11. 
Nastąpiło zatrucie atmosfery w mieście, co odczuwali mieszkańcy jeszcze przez kolejnych kilka dni (m.in. przerwano pracę w zakładach sąsiadujących bezpośrednio z „Benzylem”). Ponadto doszło do silnego skażenia gleby w miejscu akcji gaśniczej (nawet do 10 metrów w głąb), a także wody rzeki Kamiennej. Warto również podkreślić, że skutki pożaru w zakładzie mogły być znacznie poważniejsze (w głównej mierze zapobiegła temu skuteczna i szybka akcja gaśnicza) - gdyby nie doszło do odizolowania pojemników z chlorem, wówczas całemu miastu groziła ewakuacja ${ }^{32}$.

Pożar w „Benzylu” był głównym tematem nadzwyczajnej sesji Miejskiej Rady Narodowej w Skarżysku-Kamiennej, która odbyła się 9 czerwca 1986 r. Podczas spotkania przedstawiciel komitetu osiedlowego dzielnicy Dolna Kamienna wyraził kategoryczny sprzeciw wobec dalszej działalności „Benzylu”. Pożar w zakładzie uświadomił mieszkańcom, którzy od wielu lat starali się wymóc zmianę jego lokalizacji, jak duże zagrożenie dla zdrowia i życia stanowiła produkcja w fabryce i jak mało, a właściwie nic nie zrobiono, aby te zagrożenia wyeliminować ${ }^{33}$. Opinię mieszkańców Skarżyska popierały miejscowe władze, która uważały, że decyzja Komisji Rządowej (powołanej w celu analizy czynników odpowiedzialnych za pożar) o odbudowie zakładu doprowadzi do napiętej sytuacji w mieście i spotęguje lęk spowodowany potencjalnym zagrożeniem zdrowia i życia mieszkańców miasta $^{34}$. Zmianę profilu produkcji lub przeniesienie zakładu poza miasto popierały również miejskie oddziały stowarzyszeń, które zajmowały się problematyką zanieczyszczenia środowiska (m.in. Liga Ochrony Przyrody, Polskie Towarzystwo Turystyczno-Krajoznawcze, Polski Związek Wędkarski) ${ }^{35}$. Ostatecznie zakład nie został uruchomiony, jednak problem zanieczyszczonej gleby w miejscu dawnego placu składowego pozostał aktualny przez następne lata. Prace rekultywacyjne na tym terenie odbyły się dopiero w $2010 \mathrm{r}^{36}$

Do inicjatyw wpisujących się w ramy płaszczyzny regionalnej można również zaliczyć sprzeciw mieszkańców Kielc wobec decyzji o budowie elektrociepłowni

32 APK, MRN w Skarżysku-Kamiennej, sygn. 82, Wystąpienie Komisji Gospodarki Komunalnej, Mieszkaniowej i Ochrony Środowiska MRN Skarżysko na nadzwyczajnej sesji MRN w dniu 9 VI 1986 r., k. 179.

${ }^{33}$ APK, MRN w Skarżysku-Kamiennej, sygn. 176, Stanowisko Komitetu Osiedlowego nr 2 „Dolna Kamienna” w sprawie Zakładu Chemicznego „Organika-Benzyl” na Sesję Miejskiej Rady Narodowej w Skarżysku-Kamiennej, Skarżysko-Kamienna, czerwiec 1986 r., k. 24-25.

${ }^{34}$ APK, MRN w Skarżysku-Kamiennej, sygn. 27, [Pismo Przewodniczącego MRN w Skarżysku-Kamiennej do Ministerstwa Przemysłu Chemicznego i Lekkiego], Skarżysko-Kamienna, $30 \mathrm{~V}$ 1986 r., k. 69-74.

${ }^{35}$ APK, MRN w Skarżysku-Kamiennej, sygn. 176, Apel Prezydiów stowarzyszeń i organizacji, które w statutowej działalności zajmują się problematyką ochrony przyrody i środowiska - działających na terenie miasta Skarżyska-Kamiennej, Skarżysko-Kamienna, 3 VI 1986 r., k. 22-23.

${ }^{36}$ Zob.: http://www.echodnia.eu/swietokrzyskie/wiadomosci/skarzysko-kamienna/art/8742055, trwaja-prace-przy-rekultywacji-skarzyskiego-benzylu,id,t.html (dostęp: 20 XII 2015). 
w pobliżu Świętokrzyskiego Parku Narodowego oraz rezerwatu przyrody „Sufraganiec”. Deficyt energii elektrycznej, a także niewydolność sieci ciepłowniczej w Kielcach sprawiły, że lokalne władze zaczęły rozważać możliwość budowy nowej, dużej elektrociepłowni. Inwestycja ta była ujęta w planach rozwojowych miasta od połowy lat siedemdziesiątych XX w., jednak dopiero na początku kolejnej dekady przygotowano pierwsze założenia techniczno-ekonomiczne.

Rozważano różne lokalizacje nowego zakładu, m.in. wyrobisko w kamieniołomie „Wiśniówka”. Na tę lokalizację nie wyraziła jednak zgody Dyrekcja Okręgowa Kolei Państwowych w Lublinie, gdyż wiązałoby się to ze zbyt dużym obciążeniem linii kolejowej w tej okolicy; dodatkowo w wyrobisku składowane były odpady $\mathrm{z}$ przerobu kamienia ${ }^{37}$. Ostatecznie podjęto więc decyzję o budowie elektrociepłowni na obszarze Gruchawki, leżącej na terenach będących własnością miasta, oraz gminy Miedziana Góra. Wybór ten motywowano zabezpieczeniem dostaw wody (ze strumienia Sufraganiec), bliskością linii kolejowej, a także faktem, że sieć ciepłownicza prowadzona do miasta będzie dzięki temu znacznie krótsza ${ }^{38}$.

Nie brano jednak w ogóle pod uwagę konieczności wycięcia dużych połaci lasu, a także faktu, że elektrociepłownia zostanie zlokalizowana w odległości 600 metrów od rezerwatu przyrody „Sufraganiec”, a składowisko odpadów poprodukcyjnych będzie położone w jego granicach. Sama lokalizacja zakładu budziła wiele kontrowersji, również wśród przedstawicieli władz miejskich i wojewódzkich, o czym mogą świadczyć dyskusje prowadzone podczas zebrań różnego rodzaju komisji.

Warto również wspomnieć, że w trakcie projektowania i wyboru miejsca pod budowę elektrociepłowni inwestycja ta była sprzeczna $\mathrm{z}$ obowiązującymi przepisami. Ustawa z dnia 26 marca 1982 r. o ochronie gruntów rolnych i leśnych precyzowała bowiem, że na terenach znajdujących się w strefie lasów ochronnych nie można wznosić budynków i budowali z wyjątkiem tych służących gospodarce leśnej, obronności kraju i bezpieczeństwu wewnętrznemu, oznakowaniu nawigacyjnemu, ochronie zdrowia i obsłudze turystów ${ }^{39}$. Przepisy te uległy jednak zmianie w lipcu 1984 r. na mocy ustawy o planowaniu przestrzennym, która wprowadzała zmianę zezwalającą „na prowadzenie w lasach ochronnych niezbędnych prac służących koniecznej rozbudowie komunalnej infrastruktury technicznej" ${ }^{40}$. Na tym przykładzie dobrze widoczna jest uprzywilejowana pozycja gospodarki państwowej względem środowiska naturalnego, a także specyficzna gra pozorów uprawiana przez władze w tym zakresie.

\footnotetext{
${ }^{37}$ APK, WRN w Kielcach, sygn. 427, Protokół nr 6/84 posiedzenia Komisji Rolnictwa, Leśnictwa i Gospodarki Żywnościowej odbytego w dniu 10 XII 1984 r. pod przewodnictwem ob. Zygmunta Owczarka - przewodniczącego Komisji, k. 222.

${ }^{38}$ Ibidem.

${ }^{39}$ Zob.: Dz.U. 1982, nr 11, poz. 79, Ustawa z dnia 26 III 1982 r. o ochronie gruntów rolnych i leśnych.

${ }^{40}$ Zob.: Dz.U. 1984, nr 35, poz. 185, Ustawa z dnia 12 VII 1984 r. o planowaniu przestrzennym.
} 
Regulacje prawne służące ochronie ekosystemu w kraju stawały się martwą literą, kiedy w grę wchodziła rozbudowa przemysłu bądź realizacja niezbędnych inwestycji towarzyszących. Sprawa elektrociepłowni w Kielcach nie była tu przykładem odosobnionym ${ }^{41}$.

Budowa zakładu wywołała również zdecydowany sprzeciw Zarządu Wojewódzkiego Ligi Ochrony Przyrody oraz Oddziału Polskiego Towarzystwa Leśnego. W liście skierowanym do Wojewódzkiej Rady Narodowej wypunktowano zagrożenia związane z lokalizacją elektrociepłowni na obszarze Gruchawki (głównie chodziło tu o obumieranie lasów na tym terenie). W konkluzji wspomnianego pisma można przeczytać, że LOP oraz PTL „zgłaszają zasadniczy sprzeciw co do decyzji o lokalizacji elektrociepłowni w Gruchawce, która [...] została podjęta w sposób jednostronny, nie uwzględniający społecznych i gospodarczych funkcji lasów oraz ich obecnego, krytycznego stanu"42.

W tym przypadku starania lokalnej społeczności skupionej wokół organizacji przyrodniczych nie przyniosły pozytywnych rezultatów. Ostatecznie elektrociepłownia powstała na obszarze Gruchawki. W protokole dyskusji nad decyzją o zaakceptowaniu tej lokalizacji można przeczytać, że władze wojewódzkie podzielały obawy związane z budową zakładu we wspomniany miejscu, „jednak konieczność zabezpieczenia ciepła dla ogromnej rzeszy mieszkańców Kielc skłania do zaakceptowania przedstawionej propozycji”"33.

Kolejny przykładem postawy wpisującej się w ramy płaszczyzny regionalnej może być reakcja mieszkańców Torunia na awarię, jaka miała miejsce w Zakładach Przemysłu Nieorganicznego (ZPN) „Polchem”.

${ }^{41} \mathrm{~W}$ samym województwie kieleckim tego rodzaju spraw było więcej. Dobrym przykładem zupełnego lekceważenia zagrożeń ekologicznych przez władze wojewódzkie i państwowe była decyzja o lokalizacji Zakładu Produkcji Kruszywa i Kopalni Dolomitu w Brzezinach (gmina Morawica). Sprawa ta była przedstawiana na posiedzeniach GRN w Morawicy, gdzie dwukrotnie spotkała się z negatywnymi opiniami. Lokalne władze sprzeciwiały się budowie w związku z bliskim sąsiedztwem terenów mieszkalnych, a także dalszym pogorszeniem warunków ekologicznych w rejonie „Białego Zagłębia”. Nie zważając na tę opinię, Prezydium WRN w Kielcach wydało zgodę na budowę zakładów we wspomnianej miejscowości. Warto również podkreślić, że decyzja ta była niezgodna z obowiązującą od października 1984 r. uchwałą WRN w sprawie programu i kierunków ochrony środowiska w województwie kieleckim do $1990 \mathrm{r}$. Jeden z jej paragrafów zakazywał bowiem lokalizowania kolejnych zakładów uciążliwych dla środowiska na terenie „Białego Zagłębia”. Zob.: APK, WRN w Kielcach, sygn. 443, t. 1, Uzasadnienie do postanowienia Wojewódzkiej Rady Narodowej w sprawie lokalizacji inwestycji polegającej na budowie kopalni dolomitu z zakładu przeróbczego „Brzeziny” gm. Morawica, Kielce, listopad 1988 r., k. 252v.

42 APK, WRN w Kielcach, sygn. 427, [Pismo Zarządu Wojewódzkiego Ligii Ochrony Przyrody i Oddziału Polskiego Towarzystwa Leśnego w Kielcach do Komisji Leśnictwa, Rolnictwa i Gospodarki Żywnościowej Wojewódzkiej Rady Narodowej], Kielce, 19 XI 1984 r., k. 238-239.

${ }^{43}$ APK, WRN w Kielcach, sygn. 427, Protokół nr 6/84 posiedzenia Komisji Rolnictwa, Leśnictwa i Gospodarki Żywnościowej odbytego w dniu 10 XII 1984 r. pod przewodnictwem ob. Zygmunta Owczarka - przewodniczącego Komisji, k. 223. 
Wspomniane przedsiębiorstwo zostało rozbudowane i częściowo zmodernizowane na bazie niewielkiej fabryki nawozów fosforowych założonej w 1932 r. Zakład był zlokalizowany w zachodniej części Torunia. Fabryka produkowała kwas siarkowy, oleum (tlenek siarki), kwas chlorosulfonowy (chlorosiarkowy), fluorowodorowy i solny oraz szereg innych związków pochodnych siarki i fosforanów. W trakcie produkcji emitowane były do atmosfery zanieczyszczenia w postaci gazów, aerosoli i pyłów. Szczególnie toksyczne dla organizmów żywych i środowiska były dwutlenek i trójtlenek siarki oraz aerosole kwasów, które były przenoszone $\mathrm{z}$ wiatrem na znaczne odległości. O negatywnym wpływie zakładu na środowisko świadczyło:

1. Powiększanie obszaru pustyni wokół fabryki.

2. Zmiany w składzie gatunkowym roślin i zwierząt.

3. Zubożenie runa leśnego i obumieranie lasów (zwłaszcza sosnowych) w promieniu ok. $10 \mathrm{~km}$ od zakładu, szczególnie w kierunku panujących wiatrów zachodnich.

4. Stały wzrost zachorowalności (zwłaszcza u dzieci) na nieżyty dróg oddechowych, zapalenia jamy ustnej, spojówek i powstawanie różnego rodzaju uczuleń na powierzchni skóry ${ }^{44}$.

Do wspomnianej już awarii doszło z 6 na 7 lipca 1988 r. W godzinach popołudniowych i nocnych z zakładu wypuszczono chmury nieprzereagowanych tlenków siarki, które przesunęły się zgodnie z panującymi wówczas kierunkami wiatru, wywołując porażenie drzew, krzewów i roślin zielonych na obszarze ok. 700 ha lasów sosnowych, niszcząc również uprawy rolne i działkowe. Chemicznemu oparzeniu i martwicy uległy nawet liście brzóz i dębów, które są bardzo odporne na skażenie ${ }^{45}$. Maksymalna dopuszczalna emisja dwutlenku siarki do powietrza atmosferycznego wynosiła w Polsce $56 \mathrm{~kg} / \mathrm{h}$ (na mocy Rozporządzenia Rady Ministrów z 30 września 1980 r. w sprawie ochrony powietrza atmosferycznego przed zanieczyszczeniem). W ZPN „Polcham” normy te często były przekraczane nawet pięciokrotnie i wynosiły $260,3 \mathrm{~kg} / \mathrm{h}^{46}$.

Stałe zanieczyszczanie środowiska naturalnego przez toruńskie zakłady doprowadziło do aktywizacji lokalnej społeczności w celu zamknięcia lokalnego „truciciela”. Studencki Ruch Ekologiczny organizował happeningi, których głównym postulatem była likwidacja fabryki. 26 kwietnia 1989 r. protestowano przeciwko skażeniu środowiska naturalnego, a szczególnie istnieniu „Polchemu”

${ }^{44}$ AIPN Bydgoszcz, WUSW w Toruniu, sygn. 081/1416, Sprawa operacyjnego rozpracowania kryptonim „Emisja”. Materiały dotyczące skażenia atmosfery związkami siarki przez Toruńskie Zakłady Przemysłu Nieorganicznego. „Przegląd Pomorski. Miesięcznik sympatyków i członków NSZZ Solidarność" 1988 r., nr 18, k. 200.

${ }^{45}$ AIPN Bydgoszcz, WUSW w Toruniu, sygn. 081/1416, Informacja nt. okoliczności skażenia środowiska w okolicach dzielnicy „Wrzosy” w Toruniu w początkach lipca br. oraz działań podjętych i zamierzeń administracji wojewódzkiej w stosunku do zakładów „Polchem”, Toruń, 7 IV 1988 r., k. 225-229.

${ }^{46}$ AIPN Bydgoszcz, WUSW w Toruniu, sygn. 081/1416, [Pismo Prokuratury Wojewódzkiej do Ministerstwa Przemysłu], 8 IX 1988 r., k. 193. 
w Toruniu. Eksponowano hasła na transparentach: „Chcemy tlenu nie Polchemu”, "Polchem truje”, „Chcemy oddychać czystym powietrzem”, „Więcej pieniędzy na ekologię". W manifestacji uczestniczyło 800 osób. Z kolei Pomorski Klub Społeczny Zrzeszenia Kaszubsko-Pomorskiego w Toruniu przeprowadził pod toruńskimi kościołami akcję zbierania podpisów pod petycją do Ministerstwa Przemysłu w sprawie zamknięcia „Polchemu”. Pod listem podpisało się 7 tys. mieszkańców miasta ${ }^{47}$.

Mimo protestów torunian „Polchem” funkcjonował jeszcze ponad dekadę. Od 2001 r. zaczęto stopniowo ograniczać działalność zakładu, a w 2007 r. zakończono prace rozbiórkowe na terenie dawnego przedsiębiorstwa.

\section{Płaszczyzna lokalna}

Obejmuje postawy małych społeczności, które dotyczyły problemów zanieczyszczenia środowiska w miejscu ich zamieszkania - osiedlu mieszkaniowym czy też pojedynczej wsi. Z całym przekonaniem można stwierdzić, że właśnie postawy wpisujące się w tę płaszczyznę były reprezentowane najliczniej. Wynikało to prawdopodobnie z faktu, iż bezpośrednie zagrożenie lokalnego środowiska wzmagało wśród miejscowej społeczności postawy proekologiczne, zmierzające do ograniczenia tego niebezpieczeństwa.

Doskonale w naszkicowane granice płaszczyzny lokalnej wpisuje się protest mieszkańców osiedla „Uroczysko” w Kielcach wobec planów zlokalizowania na terenie dzielnicy Zakładu Leizny Kamiennej (bazaltu). Podczas zebrania Komitetu Osiedlowego nr 21 „Uroczysko-Związkowiec”, które odbyło się w lutym 1989 r., prezes Świętokrzyskiej Spółdzielni Mieszkaniowej dziwił się: „jak można w sąsiedztwie osiedli Uroczysko, Związkowiec, budowie Dąbrowy I i II, piekarni usytuować fabrykę topienia bazaltu. Taki zakład nie powinien mieć miejsca na naszym terenie" ${ }^{48}$. Co ciekawe mimo jasnych przeciwwskazań (nieprzyjemny zapach, produkty uboczne w postaci związków żelaza, wapnia, manganu i fenoli), o których wspominali lekarze, wojewódzki Sanepid wydał zgodę na budowę zakładu. Ostatecznie do rozpoczęcia inwestycji jednak nie doszło.

Wśród postaw społeczności osiedlowych na rzecz ochrony ekosystemu wymienić można również wiele działań związanych z czystością dzielnic, parków, rzek itp. ${ }^{49}$

${ }^{47}$ AIPN Bydgoszcz, WUSW w Toruniu, sygn. 081/1416, Notatka służbowa, Toruń, 27 IV 1989 r., k. 246.

${ }^{48}$ APK, UM w Kielcach, sygn. 25, Protokół spisany na posiedzeniu Komitetu Osiedlowego nr 21 „Uroczysko-Związkowiec” wraz z egzekutywą POP PZPR „Uroczysko”, radą osiedla PRON, Kielce, 21 II 1989 r., k. 194v.

${ }^{49}$ Wiele tego rodzaju spraw było podejmowanych podczas zebrań poszczególnych komitetów osiedlowych w Kielcach. Zob. np.: APK, UM w Kielcach, sygn. 5, Sprawozdanie z działalności Komitetu Osiedlowego nr 6 Szydłówek za lata 1984-1988, k. 125; ibidem, sygn. 11, Referat na 
Ludność wiejska również podejmowała działania w obronie środowiska naturalnego w najbliższym otoczeniu. Dobrym przykładem tego typu inicjatyw jest konflikt, do jakiego doszło pomiędzy mieszkańcami wsi Łostówka (województwo nowosądeckie) a władzami administracyjnymi w związku z planowaną budową wysypiska śmieci we wspomnianej miejscowości. Podczas zebrania, które toczyło się w bardzo napiętej atmosferze, lokalna ludność wyraziła swój zdecydowany sprzeciw wobec ustalonej lokalizacji. Głosy niezadowolenia związane były głównie z faktem, że wysypisko miało zostać wybudowane w odległości ok. 150-200 metrów od ujęcia wody, a ponadto w sąsiedztwie znajdowały się łąki i wodopoje wykorzystywane przy wypasaniu bydła i owiec. Z ust mieszkańców Łostówki padały wypowiedzi, że „w wypadku nieuwzględnienia postulatów [...] będą zmuszeni na podjęcie większych akcji protestacyjnych typu niepłacenia podatków i nie puszczania dzieci do szkoły" ${ }^{50}$. Wobec nieugiętej postawy wiejskiej społeczności lokalne władze partyjno-państwowe musiały ostatecznie ustąpić, a planowane wysypisko zostało zlokalizowane w innym miejscu. Podobnych spraw w całym kraju było zdecydowanie więcej ${ }^{51}$.

Podsumowując rozważania zawarte $\mathrm{w}$ artykule, warto zastanowić się, jakie czynniki wpływały na zmianę postaw Polaków względem zanieczyszczenia środowiska oraz na sam proces kształtowania świadomości ekologicznej. Z całą pewnością

konferencję osiedlową dnia 8 XII 1988 r., k. 88-89; ibidem, sygn. 15, Protokół przebiegu Konferencji Delegatów Osiedla Wietrznia-Bukówka nr 11 w Kielcach w dniu 7 XII 1984 r., k. 12v; ibidem, sygn. 16, Informacja dot. sieci handlowo-usługowej w dzielnicy Barwinek-Baranówek, Kielce 2 VII 1986 r., k. 65-67; ibidem, sygn. 20, Sprawozdanie Komisji ds. Zdrowia i Opieki Społecznej przy Radzie Osiedlowej „Bocianek”, Kielce, 28 X 1986 r., k. 47; ibidem, sygn. 21, Protokół posiedzenia członków PRON Osiedla Pakosz-Cegielnia odbytego w dniu 19 VII 1983 r., k. 85 .

${ }^{50}$ AIPN Kraków, WUSW w Nowym Sączu, sygn. 033/851, Sprawa operacyjnego sprawdzenia „Lokalizacja” - konflikt między mieszkańcami a władzami administracyjnymi w związku z planami budowy wysypiska śmieci we wsi Łostówka. Pismo Rejonowego Urzędu Spraw Wewnętrznych w Limanowej, Limanowa, 13 IV 1987 r., k. 23-24.

${ }^{51}$ Zob. np.: AIPN Łódź, WUSW w Skierniewicach, sygn. 035/65, Sprawa operacyjnego sprawdzenia „Brama” w związku z nastrojami niezadowolenia wśród mieszkańców wsi Julków z powodu utworzenia w pobliżu ich miejsca zamieszkania wysypiska śmieci przez Pókim w Skierniewicach. Informacja, Skierniewice, 17 III 1989 r., k. 17-18; AIPN Bydgoszcz, WUSW w Bydgoszczy, sygn. 044/1600, Sprawa operacyjnego sprawdzenia kryptonim „Petunia” dot. wysypiska popiołów z Elektrociepłowni Bydgoszcz II w Bydgoszczy w pobliżu wsi Wypaleniska i Makowiska. Plan przedsięwzięcia operacyjnego w sprawie operacyjnego sprawdzenia kryptonim „Petunia”, Bydgoszcz, 15 I 1988 r., k. 9; AIPN Kraków, WUSW w Nowym Sączu, sygn. 033/966, Sprawa operacyjnego sprawdzenia „Wysypisko” - niezadowolenie mieszkańców w Mszanie Dolnej w związku z lokalizacją wysypiska śmieci. Notatka służbowa z przeprowadzonej rozmowy z N-kiem MiG Mszana Dolna ob. Wojarczyk, Limanowa, 25 I 1988 r., k. 24. 
swoją rolę odegrało tu przekonanie o faktycznym i postępującym kryzysie środowiskowym w kraju. Myśli tej towarzyszyło również przeświadczenie o możliwej i zbliżającej się globalnej katastrofie ekologicznej. W Polsce obawy te zostały spotęgowane zwłaszcza po awarii w Czarnobylu. W rezultacie doszło do zachwiania przyrodniczych podstaw życia społecznego, co z kolei doprowadziło do podjęcia działań w celu zapobieżenia dalszej degradacji ekosystemu (przede wszystkim w bezpośrednim sąsiedztwie). Pojawienie się w Polsce, głównie w latach osiemdziesiątych XX w., społecznych inicjatyw proekologicznych świadczy o znacznym zaawansowaniu procesu kształtowania świadomości ekologicznej ${ }^{52}$. Ważną rolę $\mathrm{w}$ tych zmianach odegrały również ruchy i organizacje proekologiczne. Ich działalność edukacyjna oraz akcje na rzecz ochrony środowiska musiały wpływać na zwiększenie wrażliwości ekologicznej i zmianę postaw polskiego społeczeństwa względem zanieczyszczenia ekosystemu.

\section{Attitudes and reactions of Polish people to natural environment pollution in the country (1971-1989)}

(Abstract)

The article presents an analysis of the attitudes of the Polish society towards the degradation of an ecosystem occurring in three planes. Macro-scale actions are presented on the example of Chernobyl disaster and protests against the construction of nuclear power station at Żarnowiec. Afire in the Organika-Benzyl Chemical Plant and problems with the construction of a combined heat and power plant for the town of Kielce in the area of a natural reserve serve as examples of regional operations. Most numerous are examples for the local level, which include many initiatives of local municipal and rural communities. The issue of attitude of Polish people towards the pollution of natural environment in the country after the World War Two has been marginalised so far in the literature on the subject. It seems, however, that such an approach is wrong, and thorough studies in this field will certainly make a valuable contribution to the socio-economic history of the Polish People's Republic.

\section{Bibliografia (wybór)}

Burger T., Konflikty i współdziałanie. Świadomość ekologiczna i postawy społeczeństwa, w: Świadomość ekologiczna i społeczne ruchy „Zielonych” w Polsce, red. W. Mirowski, Warszawa 1999, s. 37

Górka K., Poskrobko B., Radecki W., Ochrona środowiska. Problemy społeczne, ekonomiczne i prawne, Warszawa 1998

Marody M., Sens teoretyczny a sens empiryczny pojęcia postawy. Analiza metodologiczna zasad doboru wskaźników w badaniach nad postawami, Warszawa 1976

\footnotetext{
${ }^{52}$ Socjolodzy udowadniają, że intuicyjne przekonanie dotyczące zagrożenia dla lub ze strony jakiegoś elementu przyrody, wiedza o mechanizmach zagrożeń, zwłaszcza o konsekwencjach degradacji przyrody dla jakości życia człowieka, i wywołana przez nią reakcja emocjonalna prowadzą do podjęcia działań proekologicznych. Świadomość zagrożeń stanowi zatem najmocniejszą determinantę przejścia od postaw werbalnych do zachowań, do przyjęcia behawioralnej postawy względem środowiska naturalnego; od uznawania i odczuwania wartości ekologicznych do ich realizacji. Zob.: A. Papuziński, op. cit., s. 36.
} 
Nowak S., Pojęcie postawy $w$ teoriach i stosowanych badaniach społecznych, w: Teorie postaw, red. idem, Warszawa 1973

Nycz-Wróbel J., Świadomość ekologiczna społeczeństwa $i$ wynikające z niej zagrożenia środowiska naturalnego (na przykładzie opinii mieszkańców województwa podkarpackiego), „Zeszyty Naukowe Politechniki Rzeszowskiej. Ekonomia i Nauki Humanistyczne” 2012, z. 19, nr 3

Papuziński A., Świadomość ekologiczna w świetle teorii i praktyki, „Problemy Ekorozwoju” 2006, nr 1 Poskrobko B., Jak postrzegamy ochronę środowiska, „Aura” 1987, nr 8 i 10

Wódz J., Wódz K., Świadomość ekologiczna, w: Zarządzanie środowiskiem, cz. 1, red. Z. Nowak, Gliwice 2001

Zarządzanie środowiskiem, red. B. Poskrobko, Warszawa 2007, s. 61

Jarosław Dulewicz (ur. 1986), historyk; główny obszar badawczy to historia społeczna PRL; wyróżniony w Konkursie im. Władysława Pobóg-Malinowskiego na Najlepszy Debiut Historyczny Roku (2014); współpracuje z Instytutem Yad Vashem, the United States Holocaust Memorial Museum i Muzeum Historii Polski.

Kontakt: jaroslawdulewicz@wp.pl 